\title{
From Marx and Engels to Sino-Marxism Focusing on Communist and Confucian (rujia) Notions of Loyalty and Self-Criticism
}

\author{
Gregor PAUL*
}

\begin{abstract}
The paper sketches and compares main components of Marxism, Leninism, Stalinism, and Sino-Marxism, especially Maoism. In particular, it deals with the relation between Maoism and so-called Confucianism (rujia). It is argued that this relation has been-and still is-characterized by both Maoist criticism of Confucius as well as absorption of 'Confucian' ideas. In briefly analysing commonalities and differences between the various theories and 'practices', especially the ways the Communist Party of China conceived of and asked for loyalty to the Party, reasons are given for their development, achievements, and failures.
\end{abstract}

Keywords: Marxism, Maoism, rujia (so-called Confucianism), loyalty, self-criticism

\section{Od Marxa in Engelsa do sinomarksizma s poudarkom na komunističnem in konfucijanskem (rujia) pojmu lojalnosti in samokritike}

\section{Izvleček}

Članek vsebuje orise osrednjih komponent marksizma, leninizma in stalinizma ter njihove primerjave s sinomarksizmi, predvsem $\mathrm{z}$ maoizmom. Pri tem se osredotoča zlasti na odnos med maoizmom in tako imenovanim konfucijanstvom (rujia). Avtor je prepričan, da je ta odnos temeljil (in še vedno temelji) na maoistični kritiki konfucijanstva, po drugi strani pa je (bil) opredeljen tudi z absorpcijo določenih »konfucijanskih« idej. V kratki analizi vzporednic in razlik med različnimi teorijami in "praksami«, zlasti tistimi, ki so bile povezane s konceptom lojalnosti Komunistični stranki Kitajske, avtor prikaže osrednje razloge za njihov razvoj in dosežke, pa tudi za njihove poraze.

Ključne besede: marksizem, maoizem, rujia (t. i. konfucijanstvo), lojalnost, samokritika

Gregor PAUL, Karlsruhe Institute of Technology (KIT),

Department of Philosophy.

Email address: gregor.paul@t-online.de

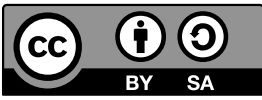




\section{Some Basic Teachings of Marx and Engels**}

Some basic teachings of Marx and Engels ${ }^{1}$ may be summed up as follows:

The world ought to be changed into a better one, characterized by a classless society in which nobody can oppress or exploit others. Thereby, the particularly Marxist idea is that of a classless society.

To be able to end class-struggle (Marx 2015,11), the world must first be adequately understood. That is, it has to be realized that it is the material but not the ideal factors that determine its features and development. Marxism thus advocates a materialist ontology and causality (ibid., 330). Thereby, materialist factors include economic ones.

Historical developments follow the laws of dialectical materialism, built on the Marxist critique of the idealistic nature of the Hegelian dialectics (see Marx 1959, 64). These laws enable both adequate description and, more importantly, reliable prediction.

The world as Marx and Engels experienced and analysed it was characterized by the oppression and exploitation of wage labourers by their employers (ibid., 7). Marx and Engels referred to the oppressed as the proletariat and to the oppressors as the bourgeoisie and capitalists. According to Marx and Engels, most workers

** I am grateful to Jana Rošker for her help in preparing this paper.

1 These central theses were mainly published in Marx 1959 and 2015, and Marx and Engels 1969. Please note that I am not reducing Marxism to the points I mention. I do not even try to list all basic teachings of Marx and Engels, but only name some of them. Also, I am aware that Marx and Engels voiced other convictions and also dealt with other topics besides those I refer to in my selection. For instance, the "young Marx" put forward a kind of philosophy of humaneness, and it was this philosophy that influenced some Chinese Marxists who-because of this influence-were not Maoists but can be called "humanist Marxists". These Chinese Marxists played an important role in the political discourse of the 1980s. The most well-known of these is Li Zehou, and according to him (2020, 334) Jin Yuelin (1895-1984), Feng Youlan (1895-1990), Zhu Guangqian (1897-1986) and Tang Yongtong (1893-1964) also "accepted" Marxism, although they were certainly no Maoists. Moreover, in the history of Marxism, many different "schools" developed. In Russia, besides Leninism and Stalinism, there was Trotskyism. In Europe, the Neo-Marxism of Georg Lukács (1885-1971), Ernst Bloch (1885-1977), and Herbert Marcuse (1898-1979) flourished. All three held that the Überbau (super-structure) can influence the socio-economic basis, and that this influence can contribute to leading to a better world. In short, this Neo-Marxism had strong humanistic features. Similar to Li Zehou, Lukács, Bloch, and Marcuse thereby emphasized the importance of aesthetics, arts and literature.

In my paper, I do not deal further with most of these schools, developments, or doctrines. The sole exceptions are the philosophies of Feng Youlan and Li Zehou, for the latter especially is an outstanding example of a Sino-Marxist who is not a Maoist. As far as I know, he never agreed with the brutality (inhumaneness) of Mao's politics and with the personality cult that culminated during the so-called Cultural Revolution and, ultimately, in the embalming of Mao's corpse. 
were forced to accept extreme oppression, since otherwise they would not have been able to survive. To end this, Marx and Engels called on the proletariat to unite and overthrow the ruling system. In order to achieve this, the use of force was regarded as necessary (Marx 2015, 360).

This process of liberation, Marx and Engels argued, ought to be led by groups who (best) understood the extant socio-economical situations and who acted in the interest of the proletariat thus, in a certain sense, representing it. According to Marx and Engels, Communist parties best fulfilled these requirements.

\section{Characteristics of Sino-Marxism²}

The version of Marxism that was developed in China comprises features formulated in the Communist Manifesto ${ }^{3}$, as well as features of Leninism, Stalinism, traditional Chinese thought, and Maoism (i.e., teachings and practices between ca. 1949 and 1976), and can thus be called Sino-Marxism. In particular, it comprises the notion of class struggle, the notion of a classless utopia, and the notions of historical dialectics and Communist party leadership. As the Manifesto already pointed out, Maoism in particular emphasized that force must be used to realize the Marxist utopia.

Whereas the notion of a world free of oppression and exploitation can express a universally valid ethical norm, the other notions are of a particularly Marxist kind. Thereby Leninism, Stalinism, and Maoism differed from the positions of the Manifesto in that they strongly emphasized, and almost relentlessly defended, Communist party leadership, even going so far as to promote the personality cult of certain party leaders, especially Stalin and Mao, who willingly gave in to the temptations of power. These personality cults even survived the deaths of Lenin, Stalin, and Mao, whose bodies were embalmed/conserved and so to say enshrined - a bewildering procedure from Marxist materialist and atheist points of view. In Sino-Marxism, and especially Maoism, the traditional rujia notion of self-cultivation was used as a means to preserve, defend and strengthen party leadership. Emphasizing the importance of self-criticism, and forcing opponents of the

2 In 2019, the journal Asian Studies published a special issue on the Sinization of Marxism. Even though several informative papers included in this issue were illuminating the topic from different views, similar to the topic of this article (see for instance Altinok 2019; Sernelj 2019; Dessein 2019; Krawczyk 2019), none of them has particularly focused upon questions regarding the connection between crucial Confucian values and Marxist axiology. The present article aims to fill this gap.

3 This is a common abbreviation of the title, the complete version of which reads Manifesto of the Communist Party (see Marx and Engels 1969). 
Party to publicly criticize themselves, it became an efficient instrument to enforce loyalty. Sympathy for the First Emperor and fajia-teachings also served to supplement Maoist justification of Party leadership (Roetz 2016). In line with this, the practices of Leninism, Stalinism, and Maoism were characterized by using force to an extent and with an intensity Marx and Engels would never have imagined, since according to them meaningful use of force required the existence of certain socio-economic conditions that did not exist before the Russian Revolution and in China during the 1950s and 60s. Mao Zedong, in his "On the Correct Handling of Contradictions among the People" and "Talk on Questions of Philosophy" (Mao 2007), insisted on the inevitability of using force even for maintaining the (intermediate, transitory) state of socialism in China.

Moreover, his notion of "synthesis" as actually a kind of complete victory over an "enemy", and his notion of permanent revolution-a rather radical interpretation of the theory of historical dialectics—served as justification for the Maoist practice of force. From a logical point of view, Mao's theory of force implied that a completely peaceful or harmonious society could, or would, never be realized.

As I try to show further in the following, the different features mentioned were partly constitutive, auxiliary, catalytic, and/or supportive of the development of Sino-Marxism. There are also other factors that contributed to this development, such as Chinese scholars' attempts to apply Marxist criteria of periodization to Chinese history (Louie 1986; Schickel 1976), though the factors referred to were probably of particular significance.

\section{General Features of Marxism that Explain Its Success}

Except for the use of force, the success of Marxism was, and is, due to features that are rather universal than of a particularly Marxist kind, namely its humane goal, this-worldliness, and its intention not only to teach humaneness, but to also put it into practice.

For who would earnestly argue or act against the idea and realization of bumanity except egoists? Especially unjust inequality-as exemplified by a class-based society - is regarded as unacceptable by most people. The desire for justice is very strong, for injustice in many cases is incompatible with the law of non-contradiction that requires that similar socioeconomic conditions, or similar individual conditions, have similar consequences. Let me state already at this junction that the classic rujia notions of ren and $y i$-i.e. the concepts of ren and $y i$ put forward in the Lunyu, Mengzi, and Xunzi-are certainly notions that, like the 
Marxist ones, are conceptions that (ideally) exclude cruelty, exploitation, and injustice. One of the explanations the Lunyu repeatedly provides for the meaning of ren is that it entails abiding by the Golden Rule, a law that anthropologists and ethnologists regard as a universally valid moral principle. However, because of its specific features, such as its emphasis on the importance of social stratification, rujia socio-political philosophy differs significantly from the Marxist utopia of a classless society.

This-worldliness is also an attractive feature of any theory and doctrine, for it promises a good, or better, human life here and now, although one must admit that millions of people regard the religious promise of an eternal afterlife as even more attractive. This, however, is relevant for our topic only in so far, as non-religious societies or cultures are more receptive to Marxism than religious ones. ${ }^{4}$ I am of course speaking in broad terms. Traditional Russian society and culture before 1917 was strongly determined by religious beliefs, especially beliefs in the existence of the Christian God. Such beliefs were obstacles that had to be overcome by force to establish Communism. In contrast, certain features of traditional Chinese culture before 1949 favoured realizing the universal features of Marxist humanism. Though religious beliefs existed, as they also do in the 21st century, they were never as widespread or powerful as in Russia. In particular, the Chinese elite, i.e. scholars and officials, rarely believed in gods, and even more rarely in the Christian God. ${ }^{5}$ In this respect, they were more rational than most Westerners. ${ }^{6}$ Their positions are also evident from the sharp criticism the Japanese kokugaka 国 学 the "School of the [our] country [Japan]", voiced against Chinese rujia, particularly the Mengzi, emphasizing that Japan was a divine country whereas China was what one could call a secular nation, dominated by extreme rationality (Paul 2013). Marxist this-worldliness manifests itself as ontological materialism and atheism. The Lunyu may be called agnostic, the Mengzi may have features that are nowadays dubbed spiritual-but not more than this—and the Xunzi argues

4 One could also put it the other way round: societies in which religious beliefs are strong, especially the belief in the existence of a God, such as the US, (traditional) Poland, or Saudi Arabia, (generally) abhor and often even fight atheism.

5 This is also the opinion of Li Zehou (e.g. 2020, 23, 28, 316-17, 321, 325). See also p. 275 below.

6 Devoted Christians supported religious wars, the pursuit and execution of "heretics", and the burning of witches. Even outstanding scholars, such as Albertus Magnus (c. 1200-1280) declared that if a certain mathematical truth contradicted Christian faith, the latter would overrule the former. Like many others he thus held that divine revelation could be more reliable than even the law of non-contradiction. All these Christians were by no means mere "victims" of their times, for even during the Middle Ages there lived Christians who opposed intolerance, superstition, and cruelty. I need not emphasize that many Chinese scholars have criticized what they regarded as Christian irrationality. 
in favour of atheism. In his brilliant essay on Marx and Confucius, Guo Moruo (1892-1978) (1999) expresses a similar view. As to the ontological question, it did not gain significance before the rise of so-called Neo-Confucianism. Interest in ontology lessens of course the importance and influence of this-worldly orientation, since its metaphysical character makes difficult intersubjective understanding or agreement.

Marx maintained that the world should not be only explained, but rather be changed into a better one ${ }^{7}$ (see Marx 1969, XI, 3), and it would be difficult to find those who would disagree. However, whereas in the West, theory and practice are often clearly distinguished, and any gap between the two tends to be deplored, classic rujia teachings, particularly the Xunzi, emphasize that it displays a lack of understanding of what may be called truth if one does not also act according to one's knowledge of the truth. The Xunzi goes as far as stating that if one is not a junzi (noble man) one cannot have knowledge (or understanding z $b i$ 知, 智). To put it briefly and somewhat roughly: according to classic rujia, understanding implies honesty, living up to one's words, and ultimately putting into practice one's insights. Marxist interest in practice, or Marxist interest in realizing theory was, and is, certainly in keeping with classic rujia teachings, but is also shared by the Communist Party of China (von Senger 2016a, 147), and Mao repeatedly emphasized the necessity of practice. (e.g. Mao 2007)

\section{Chinese Disputes about the Relation between General Ethical or Social Norms and Marxism}

From the 1950s through the end of the Cultural Revolution, the question of whether "abstract" or "general" teachings identifiable in or deducible from traditional Chinese philosophy, could, or actually did, support the realization of Communism in China has been fiercely debated among Chinese scholars and Party members. Whereas Feng Youlan (1895-1990) argued that such "abstract" or "general" inheritance of tradition was not only justified, but even advantageous to (or supportive of) realizing Communism, others maintained that there is no such thing as "abstract" or "general" teachings, but only class-related positions. Feng Youlan supported his view by reference to the notion of ren and to Engels' Feuerbach and the End of Classical German Philosophy (Louie 1986, 45, 69, 73, 74). Feng Youlan's approach was termed the "method of abstract inheritance" (chouxiang jicheng fa 抽象继 承法 (ibid., 51)). Feng's opponents insisted that a philosophy

$7 \quad$ The 11th thesis on Feuerbach reads: "The philosophers have only interpreted the world, in various ways; the point is to change it". (Marx 1969, XI, 3) 
can only mirror, or reflect, its class affiliation. Louie (ibid., 45-61) has given an excellent account of the respective disputes, while Schickel (1976) provided related material. In my opinion, though a general and/or abstract norm, such as to think and behave humanely, is understood differently in different contexts and by different people, such a norm is nevertheless conceived of as a valid principle. The very possibility of interpreting it in the specific sense desired, or required by the specific conditions given, facilitates developing, or supports, just those principles or views that are in question. For instance, ren could be used as a term that includes a Communist notion of equality. To further illustrate what I mean: it is a fact that the Aristotelian notion of "right middle" has remained, and still remains, a fruitful and inspiring notion in ethical discourse, in spite of its being developed in a slave society, and in the context of an ethics that defended such a practice. In my view "the method of abstract inheritance" did indeed facilitate the acceptance of Communism in China, be it only because it served as a kind of a psychological inspiration. Thus (as mentioned in note 1, above) Li Zehou may be right stating that Feng Youlan "accepted" Marxism, though Feng was of course no Maoist. However, one should perhaps distinguish between different phases in Feng's career, and keep in mind that his Communist opponents (also) forced him to declare approval of/compliance with Communism.

In addition, and rightly or wrongly, the Confucius cult of the 21st century certainly furthers acceptance of a "socialism with Chinese characteristics". "Ordinary" Chinese people conceive of this cult as a Communist support-a tourist opportunity provided by the Chinese Communist Party (CCP)—of (what they may regard as) Confucian teachings.

\section{Particular Features of Marxism that Explain of Its Success}

However, such general concurrences between, or overlapping of, Marxist and classic rujia as indicated by the notions of humaneness (ren), justice (yi), this-worldliness, atheism, and changing the world into a better one, do not of course suffice to explain the development of Sino-Marxism. Though they can be regarded as catalysts that made Chinese culture and society particularly receptive to the general humanistic features of Marxism, Marxism also included particular teachings that contributed to the development of Sino-Marxism, among them the doctrines of the leadership of Communist parties and the necessity of using force to realize a class-less society. The traditional rujia view that societies must be structured hierarchically, and the traditional respect for elites, as well as rujia sympathy for statism, facilitated acceptance of the Marxist idea of Communist Party leadership (as has also 
been pointed out by Louie 1986, 191-92). On the other hand, neither the rujia notion of a stratified society nor actually existing Sino-Marxism, including the idea of the leadership of the Communist Party, are compatible with the ideas of a classless and stateless society, even if acknowledging that the Chinese society of the 21 st century may be only a transitional state on the way to ultimately realizing a Marxist utopia.

Leninism, Stalinism, and especially Maoism-particularly the practice that determined the years from about 1955 to 1976-would not have come into being without the massive and brutal use of force. The same applies of course to the dictatorship of the Khmer Rouge. Even if one holds that use of force is sometimes inevitable if one wants to realize a better world, and even given that such use of force will finally prove to be a justifiable step on the way to a better world, the extent and intensity of force used in establishing Leninism, Stalinism, and Maoism remains questionable. Not that classic rujia did not include theories and justifications of bloody revolutions. Here I only mention the tianming ("Mandate of Heaven", i.e. moral justification and legitimate change of rule) doctrines in the Mengzi and $X u n z i$, but this does not change the given view. It only shows that Sino-Marxists, especially Maoists, could even utilize classic rujia thought for defending their use of force. One thing however should be clear again: The dictatorship of the respective Communist parties, and the massive and intensive use of force, was the main factor for successfully establishing Communist states. One may compare this to the "achievements" or "success" of Christianization e.g. in Central and South America. Mao's decision to rely on peasants rather than urban proletarians, however, could be justified even by reference to the Communist Manifesto.

The intricate relation between the Sino-Marxist notion of an ideal Communist on the one hand and the rujia notions of an ideal personality on the other can be illustrated by analysing and comparing the respective concepts of loyalty and criticism. In Maoism, loyalty is conceived as more or less unconditional obedience to the Communist Party of China and/or to Mao, whereas in classic rujia it is regarded as self-critical and critical devotion to the ruler(s). These teachings differ significantly from what is called Han Confucianism, Song-Confucianism, and several later versions of what has been erroneously named Confucianism. Most of these later teachings are supportive of oppressive regimes, incompatible with the Mengzi's and Xunzi's theories of criticism and tianming. I have dealt with this issue already in my book Aspects of Confucianism, published in 1990, pointing out the inhumane implications of, for example, Neo-"Confucian" spiritualist ontology and the almost logical consequence of the lixue's $l i$-concept that $l i$, "principle", (as Dai Zhen (1724-1777) rightly stated) can be used to kill people. Now, as the Maoist device of self-criticism-i.e. the demand and enforced practice 
to (publicly) criticize oneself if one deviates from the views of the Communist Party of China-and Liu Shaoqi's (1898-1969) How to be a Good Communist (1939) prove, Maoism (and to a lesser degree Sino-Marxism in general) has been strongly influenced by rujia notions of loyalty and self-criticism, though more by Neo-"Confucian" than the classic rujia notions.

Whereas the Lunyu and the Xunzi require both openness for criticism (implying a self-critical stance) and readiness to criticize, Liu emphasizes uncritical loyalty, if not obedience, to the Communist Party, thereby suggesting (or at least insinuating) that such loyalty can also be justified by rujia teachings and thus would be in line with traditional Chinese thought. Liu's reference to the rujia notion of self-criticism is already obvious from the original Chinese title of his work, Lun gongchandang yuande xiuyang, "On the Self-Cultivation of a Communist Party Member" (see also Louie 1986, 10, 43, 73, 201). "Self-cultivation" (here xiuyang) is a central term and norm of rujia, and in particular implies self-criticism. In 1998, Ruan Qing 阮青 (born 1957), in an influential essay, stated that (“Confucian”) self-cultivation (xiushen sixiang 修身思想) concords with the (Sino-Marxist) methods of criticism and self-criticism (piping ziwo piping zuofeng 批评自我 批评作风), thus also actually recognizing the influence of rujia on Sino-Marxism (see also van Ess 2016, 5, 69, 70). In the 1960s and 70s, however, "self-criticism" amounted to self-destruction. Again and again, people were forced to degrade and disgrace themselves. One of the most impressive notions of rujia philosophy was thus perverted into a means of ruthless oppression.

Except for (wrongly) justifying their methods by reference to classic rujia teachings of self-cultivation, Maoists could of course also rely on similar methods used by Stalin to oppress or even do away with opponents.

Before Khrushchev started the process of de-Stalinization (after 1953), the Chinese Communist Party, and in particular Mao, more or less followed Stalin's ideology and politics, inviting Russian advisors and technicians to visit China. Moreover, since the 1920s Chinese students studied at the Sun Yatsen University in Moscow. In 1925, a set of guidelines were published to regulate the studies and behaviour of the Chinese students (Bauer 1990, 688). This demanded unconditional loyalty to the Communist Party, denying existence of the free will of the individual, and asking for strict and unreserved criticism of the (seeming) failures of fellow students, and for servile self-criticism and acceptance of criticism (ibid., 686). One student stated that this enforced self-criticism terrified and terrorized everybody. Even if you criticized yourself honestly, there were almost always others who would go further in criticizing you. If one did not accept criticism, one was criticized even harsher. Some people even lost control of their bladders in fear (ibid., 689). 
As Liu Shaoqi puts it:

A Party member's personal interests must be unconditionally subordinated to the interests of the Party. (Liu 1939)

The test of a Party member's loyalty to the Party, the revolution, the cause of Communism is whether or not he can subordinate his personal interests absolutely and unconditionally to the interests of the Party whatever the circumstances. (ibid.)

[A good Communist] does not fear criticism and at the same time is able to criticize others with courage and sincerity. (ibid.)

Communists who have a weak sense of duty towards the Party ... fear ... self-criticism ... (ibid.)

Again and again, Liu emphasizes the necessity of what he regarded as appropriate criticism and self-criticism, supporting his arguments with quotes from the Lunyu and Mengzi. This approach has had widespread social consequences, as we can see from the following example:

During the Cultural Revolution, one Chinese woman accused herself as being worse than a sheep, comparable to a swine or a dog, continuing that even such self-criticism could not do justice to her failures. "I hate, hate myself! I hate my past, I hate my present, I hate my future ..." (Bauer $1990,713)$

Though with Khrushchev, Stalinism came to an end in the Soviet Union, its influence continued in China, particularly since Mao sympathized with its radical ideas of party rule and personality cult. Even the so-called "Great Terror" of the Moscow propaganda trials of the 1930s became a model of Maoist politics.

However, the Soviet Union almost lost its function as an informant about the West in general. This favoured a certain turning inward in China, which was favourable to strengthening the influence of traditional Chinese culture on the development of Sino-Marxism (Louie 1986). In 2018, the Beijing Academy of Wang Yangming Philosophy published a booklet entitled Cultural Confidence Eซ National Rejuvenation. Though it mainly aims to be a guide for enterprises (!), it also addresses the general reader.

The central contents can be summed up as follows: The China of the General Secretary of the Communist Party, Xi Jinping, is both determined by the leadership of the Party and by traditional Chinese culture, thus being a "socialist 
country with Chinese characteristics" (Beijing Academy 2018, 23, 154, 156). To substantiate and illustrate this, the booklet again and again quotes $\mathrm{Xi}$ Jinping and such philosophers as Confucius, Mencius, Wang Yangming (1472-1529), Laozi and Zhuangzi (4th century BC) (cf. also ibid., 120). As to important features of this combination or confluence of Marxism (ibid., 23) and Chinese philosophy, it mentions "self-cultivation" (ibid., 13, 26, 143, 209, 210), "unity of knowing and doing" (ibid., 190), the goal of establishing a "moderately prosperous society" (ibid., 146), and, particularly in reference to the Zhongyong 中庸, “The Doctrine of the Mean" (ibid., 26), and xinxue, Wang Yangming's doctrine of the heart-mind, a self-cultivation that starts with the cultivation of one's xin, the "heart-mind", and ends with including all of mankind in one's inner thoughts and feelings. In this connection, even Xi Jiping's idea of a new Silk Road is referred to as an attempt to realize the rujia idea of an all-inclusive extension of an individual's commiseration for the whole world (ibid., 144; see also ibid., 142, 143). It is also worth noting that the (rujia) "value" of "self-cultivation" is characterized as "highly agree[ing] ... on [an] individual ... level ... with [a] socialist core value" (ibid., 26, 210). The booklet is a strange mixture of propaganda and scholarship, but seems to depict the self-perception of $\mathrm{Xi}$ Jinping's leadership.

By the way, in the above mentioned essay Guo Moruo (1999) points to possible similarities among the rujia notion of datong 大同, “Great Unity", in the Liji 禮 記, “The Book of Rites”, and a Marxist utopia.

The theory and practice of self-cultivation and particularly self-criticism is an excellent example of how rujia ethics could be used to justify, and ultimately strengthen and enforce, loyalty to the Communist Party, leading to an indeed Sino-Marxist, or Maoist, conception of Marxism-Leninism. Another impressive example of Sino-Marxism is Mao Zedong's notion of the original Marxist idea of historical dialectics, which he interprets as processes of resolving contradictions. According to Mao's essay “On Contradiction” (in Mao 2007), every entity and situation is characterized by internal and external contradictionscontradictions with other entities or situations - that as such trigger historical development. Moreover, every historical situation is characterized by a principal contradiction and several minor contradictions, the resolution of which constitutes progress. Mao expressly bases his theory on his understanding of Marx, Engels, Lenin, and Stalin, quoting Lenin several times. Interestingly, he also refers to several ancient and medieval Chinese authors and texts, thus suggesting that his theory could be also supported by some traditional Chinese sources, such as Sunzi's (6th century BC) Bingfa, The Art of War, or that the Marxist notion of undialectical metaphysics can be illustrated by the philosophy of the "Confucian" Dong Zhongshu (ibid., 179-84). 
It should be noted that Mao uses an extremely wide notion of contradiction, and his definition of the law of contradiction conspicuously contradicts the logical principle of (non-)contradiction that a concept $\mathrm{c}$ or a proposition $\mathrm{p}$ is not, and cannot be, non-c, non-p or not p. Mao states: "The law of contradiction in things, that is, the law of the unity of opposites, is the fundamental law of nature and of society and therefore also the fundamental law of thought. It stands opposed to the metaphysical world outlook" (Mao 2007,101). Although I cannot enter into a discussion of this statement, it seems clear that it actually expresses an ontological and in this sense metaphysical law, whereas a law of thought is a device used to find, for example, such an ontological principle. Mao's view of contradiction thus leads to fundamental problems of Marxist epistemology.

In the context of our topic, it is more important that Mao regards criticism and self-criticism as methods by which "contradiction within the Communist Party is resolved" (ibid., 78), though, in his "On the Correct Handling of Contradictions", he even states that both kinds of criticism are means of "self-education for the people", thus conceiving of them in the same way rujia teachings of "self-cultivation" do (ibid., 138). Also, and very much in keeping with his politics especially during the Cultural Revolution, he emphasizes that "criticism and self-criticism" "should help to strengthen ... the leadership of the Communist Party", thus actually only paying lip service to the idea of "free discussion" when he maintains that "those who disapprove of these criteria can still state their own views and argue their case" (ibid., 158). It is, however, not only the rujia notion of self-cultivation that Mao could utilize to argue for self-criticism, but the even broader rujia notion of education and learning. Mao's emphasis on mass education and the education even of Party members, i.e., his repeated insistence that everybody must (more or less continuously) study Marxist theory, as well as the establishment of so-called education camps, seems to be in keeping with rujia ideas on education.

\section{Li Zehou's Humanist Sino-Marxism}

Though Maoism, in its misuse of Confucian concepts of elite leadership and self-cultivation (i.e. self-criticism), makes an extremely interesting topic for Chinese studies and political studies in general, one would not do justice to Sino-Marxism if one would not also (if again only briefly) deal with Chinese humanist Marxism as exemplified by Li Zehou's (born 1930) philosophy. This is not to just offer a more comprehensive picture of Sino-Marxism, or even a 'complete' one (which would be the task of many books). Humanist Sino-Marxism is important because it testifies to the differences that (can) exist between political 
enforced ideology (Maoism) and what people, if allowed to voice their opinions without being subjected to political oppression (or at least without being threatened to be put into prison, not to mention being tortured and publicly humiliated), would like to say, and actually dare to say. Chinese humanist Marxism is thus an example of the universal force of humaneness - independent of whether one agrees with its Marxist features or not. Leninism, Stalinism, Pol Pot's communism, Maoism (and of course also Nazism), Western Neo-Marxism and Chinese humanist Marxism all demonstrate that both cruelty and humaneness are not primarily functions of cultures, or cultural mind-sets, but rather universal human (biological) potentialities or dispositions. As noted above, Li Zehou, similar to Lukács, Bloch, and Marcuse, conceived of a pleasant aesthetic experience as an experience of individual freedom, and emphasized the importance of art and literature as a means to build a better world. On the level of theory, he accordingly put much emphasis on aesthetics. Again similar to the three Western Neo-Marxists, he thereby utilized conceptions based on the aesthetics of Immanuel Kant (1704-1804) and Friedrich Schiller (1759-1805), especially the notion of the free play of all faculties of the mind as constitutive of conscious individual freedom. Differing from Lukács, Bloch, and Marcuse, he however devoted much space to discussions of music, rites and ritual. This is of course since music (yue) and rites (li) both significantly influenced Chinese philosophical conceptions of humane culture. Li rightly conceives of himself as a Marxist insofar as he criticizes Kant's apriorism from empirical, historical and materialist points of view, explicitly relies on the early Marx's humanist thoughts, especially on what he regards as Marx's aesthetic approach to doing away with the self-estrangement caused by wage labour. ${ }^{8}$ On the other hand, $\mathrm{Li}$, in his theory building, utilizes and integrates ideas from traditional Chinese philosophy. This does not only apply to classic rujia teachings about music and rites, but also to what Li rather generally calls "the pragmatic reasoning that formed the Chinese tradition" and the "eschewing"

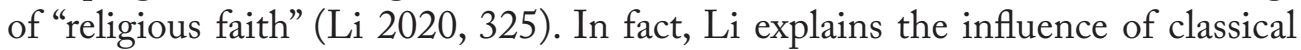
Chinese thought on the development of Sino-Marxism in much the same way as I do above. ${ }^{9}$

To put it somewhat differently, Li Zehou's Sino-Marxism is a philosophy of beauty that functions as an ethics of harmonious freedom. His main sources for this are (i) the aesthetics of Kant and Schiller, (ii) Marx's normative notion that man

8 One may argue that the young Marx's philosophy, as put forward in his Economic and Philosophical Manuscripts of 1844, is no Marxism. But since it includes an elaborate theory of estrangement or alienation, it certainly is, though it significantly differs from Leninism, Stalinism, or Maoism, or what is often called orthodox Marxism.

9 I completed these explanations before I came to know Li's respective position(s). 
should produce according to rules of beauty, and (iii) the tradition of Chinese aesthetics. (i) Li utilizes Kant's and Schiller's conception of the free play of (all) faculties of mind as constitutive of, and experiencing, (the perception of) beauty (see $\mathrm{Li}$ in $\mathrm{Li}$ and Cauvel 2006, 174). In so doing, Li approvingly refers to Kant's notion of beauty as a "symbol of freedom", and Schiller's statement that "beauty is freedom in appearance". He also agrees with Schiller's notion of the "play impulse" (ibid., 94), and Schiller's idea that men are "really free ... only ... when [they] are playing" (ibid., 94). Expressed in everyday language, Li thus maintains that the ideal human life means that what one likes to do is what one ought to do, and that what one ought to do is what one likes to do. ${ }^{10}$ (iii) Since Li, however, holds that what he regards as Kant's and Schiller's apriorism and idealism, falls short of actually contributing to building a better world (ibid., 39; Li 2018, 306, 324, 325), he supplements their philosophies with Marxist materialist humanism. As I see it, Li does not conceive of Marx's observation that "man produces in accordance with the laws of beauty" (see Li 2018, 326-35, especially 333; see also Li in Li and Cauvel 2006, 179) as a merely descriptive statement, but also as a norm, namely that man, as a free and autonomous individual, should be able to produce in such a way. In short, this would indeed mean that labour should be a kind of pleasant and pleasing creativity, doing or producing something beautiful. Li seems to believe that such a goal could indeed be achieved. In his view the history of mankind, and especially the continuous invention and use of new tools, could make possible such an achievement (Li 2018, 323-24).

The German original of Marx's statement reads "der Mensch formiert ... auch nach den Gesetzen der Schönheit" (Marx n.d.). As the context shows, this proposition is an explanation of Marx's conviction (or claim) that human beings can "truly produce" only if they are "free from physical needs". Since according to Marx "truth" in production is a necessary condition for unestranged labour, and since labour should not involve estrangement, one of its requirements is that it

10 Though $\mathrm{Li}$ does not express himself this way, his related statements imply this. For instance, $\mathrm{Li}$ characterizes beauty variously as a "unity of truth and good manifest as free sensible form in objective nature" ( $\mathrm{Li} 2018,324,331)$, as an expression of "the ideal pursued in the humanization of nature" (ibid., 333), as "the humanization of external nature or a humanized nature," and, most significantly, as the "practice of freedom" ( $\mathrm{Li}$ and Cauvel 2006, 57), "a form of freedom" (in Rošker 2018 , 85), stating that "aesthetic experience or sense of beauty ... is, in essence, a pleasant sense of freedom" ( $\mathrm{Li}$ in $\mathrm{Li}$ and Cauvel 2006, 93). As an illustration of what he means by "humanization of nature", he mentions that beautification turns eating into dining and sexual desire into love (Li 2018, 329; see also 2010, 41; most clearly, however, in Li and Cauvel 2006, 90-94). Further supportive of my interpretation are phrases such as "unification [harmonization]... of the sensuous [emotional, pleasing and pleasant] and the rational [moral]" (Li 2010, 6); unification "of the senses and reason" [faculties of desire and morality] (ibid., 10), and similar passages (ibid., 34). 
ought to be carried out following the laws of beauty. ${ }^{11} \mathrm{Li}$ thus ultimately argues that Marx's notion of individual freedom, i.e. a "true" life without any estrangement, is only possible if people (always) act according to the laws of beauty, thus turning every kind of labour in creative, beautiful work ( $\mathrm{Li}$ 2020,330; see also Li 2018, 332). ${ }^{12}$ (iii) To further support his approach, Li quotes a saying attributed to Confucius, and makes use of Xunzi's theory of $l i$ (which does not only refer to rites in a narrow sense of the notion, but also to the idea of established conventional and becoming behaviour). According to this theory, one of the main functions of $l i$ is to permit for expressing feelings without (thereby) indulging in uncontrolled emotions and/or violating social rules (see e.g. Li 2020, 111; Paul 1990). This means, for instance, that one can and should show (measured) grief at one's parents' burials. The saying attributed to Confucius, "following the desires of the heart without overstepping the bounds of right", clearly expresses the ideal of doing what one likes to do, thereby doing what one ought to do (Lunyu 2.4, quoted in Li 2010, 48). (It provokes, however, the unwanted association that this is not so difficult when you are old, for it is attributed to the 70-year old Confucius.) Moreover, Li repeatedly and correctly emphasizes that traditional Chinese culture highly valued pleasurable, aesthetic experiences.

\section{Concluding Remarks}

On its way from Europe to China, Marxism underwent several changes although certain basic teachings remained the same, especially the characterization of human history as class struggle, the notion of the communist parties as the vanguard of socio-political progress, and the conviction that realizing a communist utopia required the use of force, which was, to repeat, certainly the most important reason for the spread of Marxism, or, more appropriately, communism. In Leninism, Stalinism, and Maoism, the changes led to a decrease in Marxism's original humanism. The Sino-Marxism of the 21st century has certainly and significantly improved the material situation of the Chinese people, very much in keeping

11 Since the context of the quote is of crucial importance for an adequate understanding of Marx's position, I cite it too: "[Das Tier] produziert nur unter der Herrschaft des unmittelbaren physischen Bedürfnisses, während der Mensch selbst frei vom physischen Bedürfnis produziert und erst wahrhaft produziert in der Freiheit von demselben ... der Mensch formiert daher auch nach den Gesetzen der Schönheit." (Marx n.d.) To translate: "[The animal] only produces under the rule/dictate of direct/instantaneous physical needs, while man even produces [then when] free from physical needs, and [actually] only truly produces if free from them ... man thus also constructs/produces according to the laws of beauty."

12 Similarly, Li $(2020,313)$ maintains that "Zhuangzi's ... opposition to alienation" is an aspect (or function) of Zhuangzi's philosophy as an ultimately aesthetic one. 
with the goal of solving "the [extant] principal contradiction between the growing material and cultural desires/wants of the people and the underdeveloped ... production" (Xi Jinping, quoted in von Senger 2016a, 146; see also 154), thus establishing at least a "moderately prosperous society" (see above footnote 5). The focus on improving material welfare, and the impressive achievements made in the pursuit of this aim, should further be understood as a conscious and intentional reaction to the asceticism and poverty caused by Maoism, and as a return to Marx and Engels' ideas who, in the Manifesto, denounced as "reactionary" "universal asceticism" and "crude social levelling"- a position also confirmed by Deng Xiaoping's (1904-1997) verdict of 1996 that "poverty is not socialism" (in von Senger 2016a, 147). However, it may still be argued that this great achievement has been accompanied by enforcing too strong a loyalty to the Communist Party, and too strong a restriction of individual freedom. This issue remains even if one admits that the socialism with Chinese characteristics of the 21st century is but an intermediate step on the long way to a classless society. Socialist materialism as materialist capitalism? Regardless, Chinese Communists could quote the famous German Marxist writer Bertolt Brecht (1898-1956) who-also a convinced materialist—emphasized, "Erst kommt das Fressen, dann die Moral" (Brecht 2004, 104), the meaning of which can be expressed in English as "first comes food, then morality" "first bellies are filled, then comes morality", or "First feed me, then you can preach to me".

\section{References}

Altinok, Ozan Altan. 2019. "Mao's Marxist Negation of Marxism.” Asian Studies 7 (1): 75-96.

Bauer, Wolfgang. 1990. Das Antlitz Chinas. München: Hanser.

Brecht, Bertold. 2004. Die Dreigroschenoper. Berlin: Suhrkamp.

Beijing Academy of Wang Yangming Philosophy, ed. 2018. Cultural Confidence Eซ National Rejuvenation. Beijing: China Intercontinental Press.

Dessein, Bart. 2019. "Guo Moruo on Marx and Confucius." Asian Studies 7 (1): 129-51.

van Ess, Hans. 2016. "Sinomarxismus und Konfuzianismus: Ein dialektisches Verhältnis.” In Maoismus oder Sinomarxismus?, edited by Harro von Senger, and Marcel Senn, 55-74. Stuttgart: Steiner.

Guo, Moruo. 1999. "Marx Enters the Confucian Temple." Renditions 51: 77-86. Translated by Matthew Finkbeiner, and John Timothy Wixted. Accessed July 10, 2020. http://c1180008.ferozo.com/pdf/203.pdf. 
Krawczyk, Adrian. 2019. "Marxist Theories of Ideology in Contemporary China." Asian Studies 7 (1): 153-72.

Li, Zehou. 1994. The Path of Beauty. Translated by Gong Lizheng. Hong Kong: Oxford University Press.

— 2010. The Chinese Aesthetic Tradition. Translated from Huaxia meixue (1989) by Maija Bell Samei. Honolulu: University of Hawaii Press.

- 2018. A New Approach to Kant: A Confucian-Marxist's Viewpoint. Translated from Pipan zhexuede pipan (1st edition 1979) by Jeanne Haizhen Allen, and Christopher Ahn. Singapore: Springer Nature Singapore.

- 2020. A History of Classical Chinese Thought. Translated, with a philosophical introduction, by Andrew Lambert. New York, London: Routledge.

Li, Zehou, and Jane Cauvel. 2006. Four Essays on Aesthetics: Toward a Global Perspective. Lanham: Lexington Books.

Liu, Shaoqi. 1939. "How to be a Good Communist: Primary Source with Questions." In Selected Works of Liu Shaoqi, vol. I, edited and translated by DBQs. Published Online in February 2004. Accessed July 10, 2020.

http://afe.easia.columbia.edu/ps/china/liu_shaoqi_good_communist.pdf.

Louie, Kam. 1986. Inheriting Tradition: Interpretations of the Classical Philosophers in Communist China, 1949-1966. Hong Kong, Oxford: Oxford University Press.

Mao, Tse-Tung [Mao Zedong]. 2007. On Practice and Contradiction. (Introduction by Slavoj Žižek). London: Verso.

Marx, Karl. 1959. Economic and Philosophic Manuscripts of 1844. Moscow: Progress Publishers.

— 1969. Theses on Feuerbach. Moscow: Progress Publishers.

- 2015. Capital: A Critique of Political Economy. Vol. I, Book One: The Process of Production of Capital. Translated by Samuel Moore, and Edward Aveling, edited by Frederick Engels. Moscow: Progress Publishers.

—. n.d. "Die entfremdete Arbeit." In Ökonomisch-philosophische Manuskripte aus dem Jahre 1844. Accessed March 6, 2020.

http://www.zeno.org/Philosophie/M/Marx,+Karl/\%C3\%96konomisch-philosophische+Manuskripte+aus+dem+Jahre+1844/\%5B1.+Manuskript\%5D/ Die+entfremdete+Arbeit.

Marx, Karl, and Frederick Engels. 1969. "Manifesto of the Communist Party." In Marx/Engels Selected Works, vol. 1, 98-137. Moscow: Progress Publishers.

Paul, Gregor. 1990. Aspects of Confucianism. Frankfurt/M: Peter Lang. - 2013. "Confucian Universalism as a Driving Force of Humanity: The Timeless Lesson of Japanese Confucianism." In Confucianism in Intercultural Perspectives: Modern Developments. Papers from the Fourth International Conference of Sinology. Taipei: Academia Sinica. 
Roetz, Heiner. 2016. "Der antike Legalismus - eine Quelle des modernen Totalitarismus?” In Maoismus oder Sinomarxismus?, edited by Harro von Senger, and Marcel Senn, 75-100. Stuttgart: Steiner.

Rošker, Jana S., 2018. "From Humanized Nature to Naturalized Humans: Li Zehou's Transformation of the Classical Chinese 'Tianren Heyi' Paradigm Through the Lens of Kant and Early Marx." Frontiers of Philosophy in China 13 (1): 72-90.

Schickel, Joachim, 1976. Konfuzius: Materialien zu einer Jahrbundert-Debatte. Frankfurt/M: Suhrkamp.

von Senger, Harro, and Marcel Senn, eds. 2016. Maoismus oder Sinomarxismus? Stuttgart: Steiner.

von Senger, Harro. 2016a. "Der Sinomarxismus zu Beginn des 21. Jahrhunderts." In Maoismus oder Sinomarxismus?, edited by Harro von Senger, and Marcel Senn, 121-72. Stuttgart: Steiner.

von Senger, Harro. 2016b. 'Pragmatismus' und 'Maoismus': Rückblick auf die Tagung Maoismus oder Sinomarxismus?" In Maoismus oder Sinomarxismus?, edited by Harro von Senger, and Marcel Senn, 245-85. Stuttgart: Steiner. Sernelj, Téa. 2019. "Modern Confucian Objection Against Communism in China." Asian Studies 7 (1): 99-113. 